\title{
PLAYING POSSUM
}

We would like to draw your readers' attention to an editorial faux pas which appeared on page 508 of the October issue of the Australian Veterinary Journal. We submitted a letter entitled "Isolation of Leptospira interrogans Serotype balcanica from a Brush-tailed Possum (Trichosurus vulpecula)', but in the published article opossum had been substituted for possum in the title and throughout the text. This change is unfortunate and incorrect.

Evidently, Captain Cook in $\mathbf{1 7 7 0}$ applied the name opossum to the Australian arboreal marsupials because of a superficial resemblance to the American opossums (Walker 1968; Troughton 1973). However, American opossums belong to the Family Didelphidae which comprises 70 species, while Australian brush-tailed possums belong to the Family Phalangeridae. Didelphid marsupials are polyprotodont (having 5 pairs of incisors), whereas Australian arboreal marsupials are disprotodont (having 2 pairs of incisors). Altogether there are 40 species of Australian phalangers (possums) which have recently been divided into 3 families: Phalangeridae, including brush-tailed possums and cuscuses; Burramyidae, the pygmy possums; and Petauridae, consisting of ringtails and gliders (Kirsh and Calaby 1977).

Thus, the more correct common name to use for Trichosurus vulpecula should be the brush-tailed phalanger, but common usage favours the name possum instead, thus emphasising that this marsupial is distinct from the American opossum (Walker 1968; Troughton 1973).

Current information abourt marsupial speciation, evolution and biology can be obtained in The Biology of Marsupials by Stonehouse and Gilmore (1977).
P. J. A. PRESIDENTE, P. T. DURFEE,

University of Melbourne,

Department of Veterinary Paraclinical and Clinical Sciences, Werribee, Victoria, 3030.

15 November 1977

\section{References}

Kirsch, J. A. W. and Calaby, J. H. (1977)-The Biology of Marsupials. Ed. by Stonehouse, B. and Gilmore, D. The Macmillan Press Ltd, Melbourne, pp 9-26.

Troughton, E. (1973)-Furred Animals of Australia. 9th edn, Angus and Robertson, Sydney.

Walker, F. P. (1968)-Mammals of the World, Volume 1. 2nd edn, Johns Hopkins Press, Baltimore.

[In the Shorter Oxford Dictionary 1964 the entry under possum reads - Now colloq. 1613. Aphetic form of OPOSSUM.

The entry under opossum reads - 1610. 1. General name of the small marsupial mammals of the American family Didelphyidae mostly arboreal, some (genus Chironectes) aquatic, of nocturnal habits, with an opposable thumb on the hind foot, and tail usu. prehensile; esp. Didelphys virginiana, the common opossum of the U.S. (Collog. shortened to POSSUM, q.v.). 2. Extended to various small or moderatesized marsupials; esp. the common name in Australia and Tasmania [sic] of those of the sub-family Phalangistinae, more properly called Phalangers 1777. Editor]

\section{UNEXPECTED ISOLATION OF A NEWCASTLE DISEASE VIRUS}

For a study of antigenic relationships between Australian infectious bronchitis (IB) viruses by virus neutralisation, using the plaque reduction method, we obtained samples of IB viruses that had been isolated during the last 15 years from Australian flocks. We obtained one strain, designated G48, which had been isolated by Chubb et al (1976) and, after 4 passages in chick embryos, had been identified as an IB virus on the bases of morphology of the virion and of lesions in chick embryos and in chickens inoculated with the virus. They concluded from the results of cross-neutralisation tests in chick embryos that $\mathrm{G} 48$ virus was serologically distinct from the IB viruses in 2 commercial vaccines and from the $A$ and $T$ isolates of IB virus of Cumming (1967). Their studies were carried out using $\mathrm{G} 48$ virus at the fifth egg passage.

A sample of $\mathrm{G} 48$ virus at the sixth egg passage (hereafter referred to as original $\mathrm{G} 48$ virus), was kindly supplied by Professor R. B. Cumming. This was passaged once in chick embryos and then once in monolayer cultures of chick embryo kidney (CEK) cells. The fluid from this cell passage formed plaques in CEK cells under an agar overlay. After plaque purification (purified G48 virus), monospecific G48 antiserum was prepared in fowls.

Purified $\mathrm{G} 48$ virus was neutralised by monospecific $\mathrm{G} 48$ antiserum but not by monospecific antisera to 16 strains of Australian IB virus including A, T and the 6 strains which are incorporated in commercial vaccines. On examination of negatively stained preparations of purified G48 virus in the electron microscope by $\mathrm{Mr}$ J. E. Peterson, particles morphologically similar to paramyxoviruses were seen. No particles resembling coronavirus were seen. Using a conventional micro method, both original and purified $\mathrm{G} 48$ viruses agglutinated fowl red blood cells. The original G48 virus as received from Professor Cumming had a haemagglutination titre of 128. Haemagglutination was inhibited by Newcastle disease (ND) virus antiserum which was supplied by Dr H. A. Westbury and by the monospecific G48 antiserum. Appropriate ND virus and serum controls were included in these tests.

A further sample of the $\mathrm{G} 48$ virus at the fifth egg passage labelled " $\mathrm{G} 48 / 5 / 5$ ex R.C. Jan 74" was obtained from the Reference Collection of Australian strains of IB virus (Geering and Bruce 1970). This sample, which did not contain detectable haemagglutinins, was inoculated into chick embryos and onto CEK cells. Allantoic fluid from the inoculated eggs agglutinated both human $\mathrm{O}$ and fowl red blood cells. Plaques formed in the CEK cells under an agar overlay. ND virus antiserum inhibited both the haemagglutination and the formation of plaques. Individual plaques were picked and inoculated onto further sets of CEK cells. On formation of plaques, the agar overlay was replaced by a fluid medium for 24 hours, after which the CEK cells adsorbed fowl red blood cells.

Isolation of IB virus from G48 material at the fifth egg passage was attempted by adsorption of ND virus with fowl red blood cells followed by neutralisation of residual ND virus by monospecific ND virus antiserum with subsequent passages in chick embryos. No lesions suggestive of IB virus were seen in the embryos, which were examined 7 days after inoculation.

All eggs and fowls which were used in this work came from the SPF flocks established and used in this laboratory and known from regular serological tests to be free from infection with ND virus. Live ND virus had not been used is this laboratory for 4 years.

Our experiments strongly suggest that ND virus was present in samples of the G48 material at the fifth and sixth egg 
passages originating from Professor Cumming's laboratory. The possible presence of ND virus in materials used in the experiments described by Chubb et al (1976) should be considered.

We thank Mr J.E. Petersoh, CSIRO, Animal Health Research Laboratory, Parkville, for carrying out the electron microscopy; Dr H. A. Westbury, Department of Agriculture, Victoria, for supply of ND virus and antiserum; and Mrs U. Oxnam for careful technical assistance.

J. T. FARAGHER, C. N. WADEY

National Biological Standards Laboratory,

Private Bag No. 7 .

Parkville, Victoria, 3052.

28 April 1977

\section{References}

Cumming, R. B. (1967) Studies on Infection Bronchitis Nephrosis/Nephritis (Uraemia). Ph.D. Thesis. UniChubb, R. C., Wells, B. A. and Cumming, R. B. (1976) -A ust. vet. J. 52: 378.

Geering, W. A. and Bruce, A. I. (1970)-Aust. vet. J. 46: 76 .

\section{A reply received from $\mathrm{Dr}$ Chubb and Professor Cumming reads as follows:}

We can confirm that a Newcastle-Disease-like (ND) virus, similar to that reported by Faragher and Wadey (1977), can be isolated from samples of our G48 virus. Similarly, we have been unable to re-isolate an infectious bronchitis (IB) virus. This material at the present time (which now only has a live ND virus component) does not induce nephritis in susceptible birds.

The $\mathrm{G} 48$ virus material used in all the experiments described by Chubb et al (1976) was a single pool of material prepared in February 1973 from the fourth egg passage of affected kidneys from a disease outbreak of nephritis. This material was used up. Another pool of material was prepared from the fourth passage in January 1974 and distributed to interested parties, including the repository at the Commonwealth Serum Laboratories (G48/5 January 74 ).

It would appear that any IB virus component in the G48 material is now lost. This could have been because of prolonged storage and/or some form of interference between the two virus components on growth a second time from the fourth egg passage material.

The criterion used by Chubb et al (1976) to evaluate the challenge experiments with the G48 material was death with macroscopic evidence of nephritis (a typical characteristic of Australian IB viruses). On this basis, clear differences were seen between vaccinated birds challenged with either $T$ virus (Cumming 1967) or the G48 material. At the time of the experiments, the G48 material used induced nephritis in susceptible birds and in a high proportion of birds previously vaccinated with two commercially available IB vaccines. This in- duction of nephritis is no longer the case with $\mathrm{G} 48$ material currently available.

The cross neutralisation tests carried out by Chubb et al (1976) showed that the viruses tested could be divided into 3 groups. The 2 vaccine viruses had complete reciprocal neutralisation. The $T$ and $A$ viruses had complete reciprocal neutralisation and the G48 material neutralised only itself. All 5 viruses were neutralised by $A$ virus serum.

The neutralisation of $G 48$ virus by $A$ virus serum lends some support to this, at the time, being predominantly an IB virus, or, conversely, that the A virus serum could neutralise ND virus. It is unlikely that the birds used to produced the antibodies (which were all derived from a homogeneous group) had ND virus antibodies otherwise all the various IB sera would have neutralised the ND component of $G 48$ virus in a similar manner to the $A$ virus serum. There has been no subsequent evidence that the $A$ virus material used to produce its homologous antiserum had an ND virus component. It is unfortunate that this work cannot be replaced now. Nevertheless, similar differences berween Australian IB viruses were indicated by Westbury (1970) and more positively by Wadey and Faragher (unpublished data) in recent time.

In conclusion two points are worthy of mention: firstly, there is increasing evidence that ND virus is widespread in Australia and needs to be looked for as a contaminant when attempting to isolate viruses (Ma and Cumming - unpublished); secondly, the points highlighted by the Chubb et al (1976) paper that more than one serological variant of $1 B$ existed in Australia is supported by Wadey and Faragher (unpublished) and that the resistance induced by Australian IB vaccine strains can be over-come by some Australian variants of IB virus is further supported by Cumming (1976). The contention that only the variant of IB virus exists in Australia is no longer valid.

R.C. CHUBB,

P.O. Box 36, Glenorie,

New South Wales, 2157.

R.B. CUMMING,

Department of Biochemistry \& Nutrition, University of New England,

Armidale, New South Wales, 2351

5 October 1977

\section{References}

Cumming, R. B. (1967)—Studies on Infection Bronchitis Nephrosis/Nephritis (Uraemia). Ph.D. Thesis. University of New England, Armidale.

Cumming, R. B. (1976)-Proceedings 1st Australian Poultry and Stock Feed Convention (Melbourne) p 147.

Chubb, R. C., Wells, B. A. and Cumming, R. B. (1976) -A ust. vet. J. 52: 378.

Faragher, J. T. and Wadey, C. N. (1977)-Aust. vet. J. 53:

Westbury, H. A. (1970)-Proceedings XIV World Poultry Congr. Madrid, Spain, p 197. 